\title{
Conditions for Workplace Learning Among Professional 'Temps': A Qualitative Study of Temporary Agency Nurses in Sweden
}

\author{
Anna Berg Jansson ${ }^{1}\left[\right.$. Åsa Engström ${ }^{2}[$
}

Received: 12 May 2021 / Accepted: 17 January 2022 / Published online: 28 February 2022

(c) The Author(s) 2022

\begin{abstract}
Adopting a theoretical perspective that acknowledges both formal and informal learning as crucial and emphasises reproductive and developmental learning as complementary, this article analyses and discusses temporary agency nurses' experiences of working and learning, focusing on conditions for workplace learning. This provides opportunities to address questions about conditions for the integration of work and learning in a work situation characterised by flexibilization and individualisation. More specifically, among individuals moving between different organizational contexts rather than working at 'a' (single and stable) workplace provided by the employer. By presenting findings based on a thematic analysis of 21 interviews with individual temporary agency nurses working in Swedish health care, both opportunities and challenges for workplace learning is highlighted. While opportunities for informal learning linked to the movement between various client organizations as well as to nursing as common ground and as valued and recognized competence, is identified, at the same time, challenges connected to both formal and informal learning, are also illuminated. Regarding informal learning, challenges in terms of varied and general support and feedback as well as scarce opportunities and low expectations for the temporary agency nurses' participation in development work in daily work/at client organizations, is identified. The findings thus also illuminate a risk for temporary agency nurses adjusting to prevailing working conditions rather than engaging in developmental learning. Regarding formal learning, challenges in terms of few opportunities for planned learning activities, is identified. All in all, the findings illuminate conditions for workplace learning for temporary agency nurses as clearly dependent not only on the offers of specific temporary work agencies and client organisations, but also on temporary agency nurses' interest in and views regarding responsibility for learning, and thus highly varying.
\end{abstract}

Extended author information available on the last page of the article 


\section{Introduction}

This paper highlights conditions for workplace learning among temporary agency nurses employed by temporary work agencies but performing daily work in client organisations. This provides opportunities to address questions about the conditions for integrating work and learning in a work situation discussed as characterised by flexibilization and individualisation (Allvin et al., 2006; Garsten, 2008; Sennett, 2000).

Workplace learning — that is, adult learning at or related to work (Illeris, 2011) builds on the integration of work and learning. Thus, in addition to formal learning, informal learning, that occurs in parallel when working (Ellström, 1996), is deemed important. In fact, workplace learning is described as 'mostly informal in nature' (Tynjälä, 2008, p. 132) and thus as closely related to daily work and working conditions. Accordingly, in this paper, conditions for workplace learning is examined in relation to both temporary work agencies and client organizations. Unlike in standard employment, in which conditions for workplace learning are closely related to the employing organisation, we regard these conditions as divided for temporary agency nurses, with matters related to daily work handled by client organizations and longerterm issues addressed by temporary work agencies (Håkansson \& Isidorsson, 2015). Furthermore, although the organization of work '... sets the context and conditions for learning, it is still the reciprocal interaction between the individual and the workplace that determines learning' (Tynjälä, 2008, p. 141, cf. Billett, 2010). Thus, in addition to conditions related to the client organization and temporary work agency, subjective factors related to individuals' willingness and their interest in learning (Ellström, 2001, 2004), is also examined and discussed.

Indeed, workplace learning can be emphasised as especially important in the studied context as learning constitutes an essential aspect of professional work (Freidson, 2001). Being able to develop competence continually is thus essential to professionals (Billett et al., 2014, p. xviii) and learning opportunities are considered vital to enabling nurses to thrive and stay in the profession (Ahlstedt et al., 2019, cf. Puhakka et al., 2021). At the same time, temporary agency work is described to imply a 'collective individualization' that undermines the social aspects of work and detaches 'temps' from collegial ties (Garsten, 1999; 2008). As collegiality is a fundamental resource in professional work (Svensson, 2008) and intra-professional relations are crucial to nurses' learning (Billett et al., 2014; Kyndt et al., 2016), this is relevant. In addition, in line with previous research highlighting temporary agency workers' learning as challenging (see for example Augustsson, 2014; Håkansson \& Isidorsson, 2015), previous studies show that temporary agency nurses risk missing out on important learning opportunities (Augustsson, 2016; Berg Jansson et al., 2020; Charnley \& Arnold, 2006) and them suggest a need for improved conditions of training and competence development for temporary agency nurses (Manias et al., 2003; Hass et al., 2006). At the same time, important nuances between diverse contexts of temporary agency work are identified, for example, how 'the likelihood of participating in training grows the higher the occupational group' (Forrier \& Sels, 2003, p. 652 ) and how individuals with positive attitudes about this associate it with positive aspects, such as opportunities for learning (Bosmans et al., 2015; Bellaagh \& Isaks- 
son, 1999). Forrier \& Sels (2003) discuss how 'varying jobs may also create opportunities to learn' (p. 664) and calls for more detailed studies of learning opportunities in temporary agency work. Indeed, in Sweden, the choice of working as an temporary agency nurse is described as an active choice (due to employability) (Allvin et al., 2003), and some learning opportunities for temporary agency nurses is indicated (Berg Jansson et al., 2020).

To advance the above-mentioned research, the overall aim of this paper is to analyse and discuss temporary agency nurses' experiences of working and learning from a workplace learning perspective, focusing on the following research questions. What conditions for workplace learning can be identified? What enabling and constraining features can be identified in agency nurses' work situation, and how can these be discussed in relation to adaptive and developmental learning, respectively?

In fact, from 2011 to 2018, the total cost for hiring of staff in Swedish regions ${ }^{1}$ delivering health care via health care centres and hospitals ${ }^{2}$ (SALARa, n.d.) more than doubled. Although some regions have lately reduced hiring in certain areas, the total costs for temporary agency nurses continue to increase, rising by $26 \%$ in the last quarter of 2018 (SALARa, n.d.) and 6\% in the first six months of 2020 (SALARb, n.d.). In Sweden, client organizations (within the public sector) is described as compelled to hire temporary agency nurses due to problems in recruiting qualified staff, just to secure stability (Håkansson \& Isidorsson, 2016). All in all, this reflects how temporary agency work among nurses has increased lately in Sweden and thus also, some nurses' choice of a temporary work agency over a 'traditional' public employer: municipality or health care region. Similar trends are noted elsewhere such as in Norway (Knutsen, 2019), South Africa (Ronnie, 2020), the UK (Kirkpatrick et al., 2018) and Italy (Cicellin et al., 2015).

To address these matters, the conceptual framework will be outlined. Thereafter, we present the study's context, the research approach and some methodological considerations. The findings are then presented, and the article ends with a discussion, conclusions and suggestions for future research.

\section{Conceptual Framework}

The focus of this study concerns conditions for workplace learning for temporary agency nurses with departure in a conceptual framework highlighting workplace learning as related to work (organization of work), social relations and individual factors, and a balance between formal and informal learning as well as between repro-

\footnotetext{
${ }^{1}$ In Sweden, a significant proportion of all public services are provided by municipalities and regions financing themselves mainly by taxes (SALAR, 2021). Regarding health care, 290 municipalities are responsible for elderly care, home care and social care, while 21 regions are responsible for all individual health services (primary, psychiatric and specialist health care). While many primary care providers (municipal level) are private, most Swedish hospitals (regional level) are publicly owned (yet both publicly and private owned health care facilities are publicly funded) (OECD, 2017).

${ }^{2}$ From 2,453 million SEK (2011) to 5,431 million SEK (2018), figures corresponding primarily to the hiring of doctors and nurses in care facilities run by regions under their own management; costs for purchased private units or 'care choice' are not included (communication with SALAR, 2019-11-26).
} 
ductive and developmental learning, as decisive (Ellström, 2001; 2004, Eraut 2011; Billett, 2004). Furthermore, the concept of a learning environment (Billett, 2001; Ellström, 2001; Fuller \& Unwin, 2004), is highlighted due to its potential to distinguish whether the conditions that characterizes the temporary agency nurses daily work will facilitate or hinder learning in daily work.

In relation to work, formal learning implies planned learning activities, such as courses and study visits, that often occur 'off the job', generate formal knowledge and include the awarding of credit, etc. (Ellström, 1992, 1996; Eraut, 2011). It involves activities to help individuals acquire specific knowledge and skills useful in daily work (Manuti et al., 2015). Informal learning implies relatively unplanned learning in everyday work via for example self-directed study, and mentoring, generating mainly implicit or tacit knowledge (Ellström, 1992, 1996; Marsick \& Watkins, 2001). This embraces learning directly connected to work, for example, when individual employees or work teams solve problems or test new ideas, showing that workplace learning also occurs in situations not usually intended for learning (Manuti et al., 2015). 'Incidental learning' represents a distinct form of informal learning. ${ }^{3}$ However, unlike other informal learning, which can be deliberately encouraged, it 'takes place although people are not always conscious of it" (Marsick \& Watkins, 1990, p. 12). Thus, it may result in dysfunctions, such as passivity and an impaired problemsolving ability. Accordingly, besides being highly contextualised, informal learning brings more unpredictable outcomes than formal learning (Hager, 2011), so the latter is considered crucial to exploiting informal learning effectively (Slotte et al., 2004; Ellström, 2001).

Regarding conditions for workplace learning, in theory, both objective and subjective factors are emphasised as decisive; the former include the nature and complexity of work tasks and how work is distributed and organised, whilst the latter include individuals' attitudes, willingness and interest in learning, which are important components of individual 'learning readiness' (Ellström, 2001, p. 426). According to Billett (2010), workplace affordances comprise access to activities and interactions which provide opportunities for both new learning and for refining and honing previous knowledge. Thus, it is essential not only to focus on objective factors (workplace affordances), but also to consider subjective factors contributing to and shaping learning. More specifically, Ellström (2001) underlines the following factors as critical: the learning potential of the task, opportunities for feedback, evaluation, and reflection on the outcomes of work actions, employee participation in handling problems and developing work processes, and learning resources (p. 425). Tasks with a high learning potential are characterised by a great degree of discretion and autonomy, opportunities for learning, a holistic understanding of organisational matters, and encouragement of and opportunities for collaboration with other people (Ellström, 1992). Tasks enabling versatility and variation through job rotation also promote learning at work (Ellström, 1992). However, the above provide 'necessary rather than sufficient conditions for learning' (Ellström, 2001, p. 425) and must be

\footnotetext{
${ }^{3}$ Defined as 'a by-product of some other activity such as task accomplishment, interpersonal interaction, sensing the organizational culture, trial-and-error experimentation, or even formal learning' (Marsick \& Watkins, 1990, p. 12).
} 
accompanied by subjective factors, such as knowledge and self-confidence, as well as learning resources, such as time, to promote learning. Time is essential for participation in formal learning as well as for feedback and reflection on the outcomes of work actions (Ellström, 2001). Indeed, Eraut (2004, 2011) stresses that a significant part of workplace learning requires that individuals dare to expose themselves to 'the unusual' (challenges). As self-confidence and support increase the possibility of taking on such challenges, these become critically important (Eraut, 2004; 2011). Social elements are also deemed crucial; workplace cultures promote learning by encouraging critical questioning, tolerating mistakes, fostering equal relationships (Ellström, 2004), and relations with colleagues and managers are prerequisites for feedback, support, etc. This is also emphasised by Billett $(2001,2004)$ who discusses workplace learning as an participatory practice and underline direct or indirect guidance through interaction between novices and experts as crucial. As Hilkenmeier et al. (2021) point out, a more recent contribution providing a comprehensive model of work related learning was introduced when Tynjälä (2013) who presented the so called "3-P model" in which she adapts Biggs' (1999) discussion of presage, process and product to a workplace context, and in which many of the above discussed factors are combined. In this model, presage illuminate factors related to the individual learner, such as commitment and self-confidence, as well as situational factors, such as manager support and collaborative climate. As stressed by Tynjälä (2013), these factors will affect the learning process indirectly rather than directly. More specifically, it is the learners' interpretation of these factors that is important regarding whether they will promote learning or not. The process component, on the other hand, illustrates different kinds of learning activities such as learning through experience, collaboration, training etc. Lastly, through the product component, Tynjälä (2013) illustrates different kinds of 'products' of learning — ranging from personal development to increased productivity.

Lastly, Ellström $(2001 ; 2011)$ underlines how the relationship between the individual and the context affects the outcome of the learning process by defining two major modes of learning. Adaptive learning occurs when individuals learn in situations with given tasks, goals and conditions without critically reviewing (questioning) them. Developmental learning happens when individuals question prevailing conditions, goals and tasks with an intention to influence them, focusing on identifying and formulating problems, learning to handle complex situations, etc. These modes of learning are complementary and proceed alternately (Ellström, 2001). Adaptive learning can reduce errors and provides stability for individuals and organisations but can also imply adaptation to given working conditions. Developmental learning responds to the 'not given' (surprises, needed changes), demands critical analysis and questioning and can thus drive change and innovation (Ellström, 2001). Thus, the following two types of learning environments can be distinguished. Enabling learning environments refers to '.. working conditions and practices that are likely to promote a balance between reproductive and developmental learning, that is, where individuals are able to alternate between these two modes of learning' (Ellström et al., 2007, p. 86). Constraining learning environments instead refers to '... conditions and practices that are likely to constrain both reproductive and developmental learning, or to 
promote reproductive learning at the expense of developmental learning' (Ellström et al., 2007, p. 86).

Below, these matters are addressed by drawing on data from interviews with Swedish temporary agency nurses about their experiences of work and learning.

\section{Method}

\section{Study Design}

A qualitative study was designed, guided by an ambition to reach a deeper understanding of prevailing conditions for workplace learning characterizing temporary agency nurses work situation. Indeed, qualitative studies are discussed as more suited to understanding the more informal aspects of workplace learning (Forrier \& Sels, 2003). Inspired by Nowell et al.'s (2017) description of how to conduct analysis in order to meet the trustworthiness criteria as defined by Lincoln \& Guba (1985), we strove to report the process of analysis as clearly and transparently as possible. For example, in order to ensure confirmability and transferability, unedited quotes are provided throughout the results to show that they are grounded in the empirical material, as well as, to achieve dependability and conformability, to provide a detailed description of the study design, data collection and analysis process. All data collection and handling were conducted in accordance with the Swedish Research Council's (2017) ethics guidelines on information, consent, confidentiality and data usage.

\section{Participants and Data Collection}

In this study, in-depth interviews were conducted in 2018-2020 with 21 temporary agency nurses recruited through purposive sampling (Patton, 2015) with the following criteria: being a registered nurse for at least one year and having experience of working as an temporary agency nurse at a Swedish hospital and/or health care centre. The temporary agency nurses had experiences of various temporary work agencies and client organizations, mirroring how temporary agency work implies moving between various organizational contexts and between shorter and longer assignments. The interviewees ( 17 women, 4 men) had from 2 to 40 years of experience as nurses (mean: 19.4 years), from 0.5 to 14 years of experience as temporary agency nurses (mean: 2.8 years), and thirteen were specialist nurses in intensive and critical care, anesthesia, operating theatre, prehospital care and pediatrics ${ }^{4}$. The participants were recruited primarily through a web survey disseminated via the Swedish Association of Health Professionals (trade union and professional association for registered nurses) and via a Facebook group for temporary agency nurses in Sweden. Those participating in the survey could indicate an interest in being interviewed. Five interviewees were recruited through personal contacts. Information about the study and conditions for participation were included in the survey and repeated verbally

\footnotetext{
${ }^{4}$ That is, while all ANs were registered nurses' (with a three-year Bachelor Program in Nursing), some ANs had at least one-year post-graduate education in specialization at an advanced level.
} 
prior to each interview. Before the interview, the participants could ask questions and approve the recording of the interview.

The interview guide focused on the choice to work as an temporary agency nurse and on experiences of daily work and learning under the following themes: work; background (education, work experience, choice of profession); previous and current employer(s) (overall experiences and choice of employer; to work as an regular nurse or temporary agency nurse); relations and daily working conditions at client organizations and temporary work agency respectively. The interviewees were encouraged to talk freely, and follow-up questions that enhanced the richness of the data. The interviews lasted from 45 to $90 \mathrm{~min}$ and were audio recorded and transcribed verbatim.

\section{Data Analysis}

The interviews were analysed manually and thematically through a reflexive data analysis procedure to identify patterns of interest in relation to the aim of the study following Braun \& Clarke (2006). First, the interviews were read several times to understand each interview as a whole and grasp passages with an important meaning related to the aim of this paper. Hence, statements related to conditions for workplace learning, sensitized with departure in the conceptual framework, were coded and interpreted. Passages identified as relevant were then analysed more thoroughly, and meaning units were identified. Later, these excerpts were condensed and grouped into several themes illustrating what we interpreted as related to conditions for learning. For example, statements regarding how the 'continuous movement' were experienced in terms of opportunities for 'more knowledge' were regarded as an illustration of how movement were linked to opportunities for learning in daily work. This initial thematization was then followed up by returning to the interview transcripts to evaluate our interpretation, that is by interpreting coded statements in relation to the context of each interview as well as through critical discussions between the two involved researchers for making sure that these themes mirrored a 'patterned response or meaning within the data set' (Braun \& Clarke, 2006, p. 82). Thereafter, subsequent in-depth readings of these initial themes were performed and from this we were able to identify three overarching themes under which the initial themes could be grouped and form subthemes, as presented below.

\section{Limitations}

As described, this qualitative study is based on interviews with 21 temporary agency nurses and thus, the findings can be related to this specific group of interviewees and must be considered in relation to this specific data. Furthermore, in terms of limitations, one should notice that the interviewees volunteered to participate in the study and thus, may have experiences other than those who choose not to participate. For example, one can assume that those who were interested to participate in the study were motivated by either a more positive or negative (critical) view on temporary agency work. That is, they were driven by an ambition to highlight either advantages or disadvantages with this way of working. However, regarding this, as the major- 
ity of the interviewees emphasised both advantages and disadvantages we identified no signs of such bias in the material. Finally, the analysis were driven by analytical questions focused on conditions for workplace learning, and can thus be defined as a 'theoretical' thematic analysis (Braun \& Clarke, 2006, p. 84). Thus, the findings do not provide a rich description of all parts of the material but focus on those parts that relate to workplace learning.

\section{Findings}

During analysis, three themes and seven subthemes were identified. Two of these themes; 'Learning as enabled' and 'Learning as constrained', illuminated factors related to temporary work agency and client organization through two versus three related subthemes, while the third theme; 'Diverging views on and evaluations of prevailing working and learning conditions', illuminated factors related to individual temporary agency nurses through two related subthemes. Furthermore, during analysis, some tensions between these themes were also discerned and these will be further elaborated in the following discussion section.

\section{Learning as Enabled}

This first theme illuminate how expressions of what we interpreted as illustrating learning as enabled were related to: "nursing as common ground and as valued competence' and 'movement as challenging and developing', also constituting the two subthemes here.

Nursing as common ground and as valued competence.

Based on the analysis, nursing emerged as constituting common grounds for regular nurses and temporary agency nurses. The temporary agency nurses described their daily work as regular nursing; how they worked with regular nurses and used their nursing competence. No crucial difference between working as an regular nurse or an temporary agency nurse were described, and examples of them sharing knowledge and supporting each other in daily work, occurred. For example, one temporary agency nurse emphasised the following about demanding situations, such as cardiac arrest: 'When such happens, then there is no difference between me and an regular nurse. I mean, then we are all colleagues and can ventilate. Share knowledge, and emotionally' (I6).

Work as an temporary agency nurse were also linked to feeling more valued and appreciated, and that one's competence were more recognized, than when working as an regular nurse. One interviewee described how arriving to client organizations meant having more eyes on you as then 'regular staff needs to learn more about your capacity' (I6). Another interviewee said:

The doctors appreciate that I can, that I am skilled, and then, the whole team [...]. The other day, for example, an assistant nurse came up to me and 'said thank you! I feel so safe with you!' and I mean you do not hear that much when you are a regular nurse. Unfortunately. (I11) 
Narrations of how regular nurses often responded with relief (positively) when temporary agency nurses arrived due to a strained staffing situation at many client organizations, also occurred: 'Everyone always becomes happy when I arrive! That was not the case before, in other workplaces, I almost said, no, but in a different way' (I2). Similar narrations of how temporary work agency managers, as opposed to previous managers at public employers, strived to meet temporary agency nurses needs and requests in order to retain them, also occurred. In relation to this, one temporary agency nurse said: 'I feel that I mean something. That I am being seen and heard' (I1). Another interviewee said:

The temporary work agency is very responsive. They start from me and are interested in me. That only is very different for me as a nurse, in that role [...] I mean, if one is working for the municipality or a health care region, then, no one notices me. It is almost inconvenient to notice me. It is someone who needs to do this task, yes, but who that is, that is not important. (I12)

This theme illustrate how nursing as common ground provided opportunities for regular nurses and temporary agency nurses to share knowledge and support each other in daily work. Furthermore, how daily work as an temporary agency nurse were linked to feeling more appreciated and valued, and that one's competence was more recognized and visible, than when working as a regular nurse.

Movement as challenging and developing.

During analysis, competence and experience emerged as decisive in relation to challenges linked to the continual movement between various client organizations, such as constantly meeting new routines, working methods and colleagues. This was illustrated by recurring narrations of how one 'relied' much on one's experience and competence, and how one never would have worked as an temporary agency nurse at the start of one's career. In fact, many interviewees also emphasised themselves as competent, experienced and confident.

This movement also emerged as linked to opportunities for experiencing diverse contexts and, thus, as providing opportunities for 'more knowledge' (I6). As illustrated below, some interviewees explicitly spoke of this in terms of learning opportunities:

Only changing workplace was really competence development for me! I felt that I had stagnated a lot; it was the same people and maybe also a certain kind of operations. I almost never got the opportunity to participate in certain types of operations. (I10)

Similar narrations such as 'you learn different things in each place' (I5) and 'you learn a lot yourself, as you get to see many different ways of doing things' (A12), recurred. One interviewee, stressing learning as an appealing aspect of temporary agency work, concluded:

Everyone should try working as an temporary agency nurse, because this has really taken me further and further away from my comfort zone. I have worked 
in areas that I never thought or planned to do! One very easily becomes home

blind, so this is really useful! (I9)

Indeed, this quote captures the essence of this sub-theme, namely how working as an temporary agency nurse emerged as linked to opportunities to experience diverse work contexts and to certain challenges (moving outside one's comfort zone). In turn, how these aspects required competence and enabled learning and development in daily work.

\section{Learning as Constrained}

This second theme illuminates how expressions of what we interpreted as illustrating learning as constrained were related to: 'Limited participation and contribution at client organizations', 'Relations at client organizations as decisive but varying', and 'temporary work agency as employer at distance with varying offers', also constituting the three sub-themes here.

Limited participation and contribution at client organizations.

During analysis, temporary agency nurses' participation and contribution at client organizations emerged as limited, and were illustrated by narrations of how they usually did not participate in meetings, or, in planning and development work at client organizations. One temporary agency nurse pinpointed how she never became 'involved in their community, in their annual plan, what they are planning to do ahead' (I11), while another interviewee pointed out how she could initiate development by comment on routines, giving advice but concluded: 'But I do not drive such processes now as an temporary agency nurse, no. I did it as an regular nurse' (I4). One interviewee described how she, if participating in a (client organization) meeting, 'still were not really participating' (I13), as she lacked information, would not be further involved or assigned responsibility. Consequently, competence related to leadership, development work and supervision of nursing students was described as usually not applied. Few opportunities for temporary agency nurses to participate in courses and lectures organised by (at) client organizations were also mentioned. Some interviewees explicitly mentioned this as a difference from working as an regular nurse:

At the health care region, where I used to work as an regular nurse, there were a bureaucratic organization securing this well 'we need to develop this and that' and thus, provided local courses for the staff to apply for [...]. But, this is not something temporary agency nurses is offered, I mean, the client organization does not approach temporary agency nurses saying 'it would be great if you could take this course because we need to develop competence within this area'. (I9)

In turn, these 'limitations' were linked to narrations of how temporary agency nurses were at the client organization 'just to work' (I11), and to unwritten rules and expectations regarding their contribution. For example, one interviewee said: 'If you are good at what you are doing, and finish your program, then it fills up [...] That is 
normal and it is the same at all places. It is nothing secret or so, that's simply the way it is. You work' (I11) Another interviewee said he had realised how being an temporary agency nurse included to simply work his hours, 'do it well and professionally and support through practical work' (I8). Similar descriptions, illustrating a division of work between temporary agency nurses and regular nurses; how the latter were responsible for 'all work tasks' while the former worked 'hard but more limited', recurred.

Unwritten rules and expectations was instead illustrated by descriptions of how temporary agency nurses should 'keep a low profile and only do one's job, that is, not make much of a fuss' (I7) and uncertainty about how comments or advice would be received. One interviewee said she loved to 'teach', and were happy do to that, but emphasised how she only did so if explicitly asked as she were 'only a name on a list' and 'as it is important not to be too good, to stand out' (I9). Another temporary agency nurse said no client organization manager had ever tried to benefit from her competence by giving her opportunity to evaluate routines, and that she had been told that she was 'not employed to think but to do' (I7). Similar narrations, such as how one had 'realized the difficulty with contributing to development if not requested' (I8), recurred.

Although temporary agency nurses participation were described as partly affected by the length of assignments - became less limited when being a longer period at a client organization and vice versa - this subtheme illustrate how the temporary agency nurses' limited participation and contribution at client organizations were linked to both structural (temporary agency nurses as 'just working') and cultural aspects (norms and values regarding what to do/not to do as an temporary agency nurse).

Relations at client organizations as decisive but varying.

During the analysis, relations to client organization managers and regular nurses emerged as decisive for feedback and support in daily work, and were illustrated by recurring narrations of how temporary agency nurses were partly dependent on regular staff to access information about routines and equipment, by asking regular staff, reading regular nurses' emails and posted directives, for being able to 'adapt' to routines and so on. Indeed, one interviewee emphasized how a client organization manager, keen to mediate directives etc., helped greatly by providing 'good insight into how they want the work to be carried out' (I6). Another temporary agency nurse described how she handled possible learning needs related to different systems or medical equipment at client organizations 'by trying to catch a nurse or a doctor who happens to come by, simply asking and learning by doing' (I5). By contrast, some temporary agency nurses explicitly problematized not being part of the regular information flow at client organizations and not having access to internal email. For example, one interviewee described how he 'asked around' to gain control and how he had tried to gain access to internal email at a client organization where he had been regularly (in order to be updated), but without success. He concluded: 'So, then, you simply have to accept that routines change or that things look different when you get there next time, and, you just have to adapt' (I7).

All in all, relations with client organization managers and regular nurses emerged as functional but as clearly varied. Consequently, opportunities for feedback and sup- 
port emerged as varied and spontaneous rather than structured. The following quote illustrates this:

In some places, you are completely invisible to the managers. [...] I've had two different experiences; in one place was a manager I hardly saw, but she knew exactly what I did and what happened. [...] But then there are those who do not even notice, they just say, 'Hi welcome', and that's it! They do not care at all. It's been a big difference in the places I've been. (I11)

Here, again, time emerged as important, namely as longer assignments were linked to more developed relations with regular staff and, thus, more opportunities also for support, and vice versa. For example, one temporary agency nurse said:

Most often, during shorter assignments, a week or so, regular nurses or client organization managers never provide any kind of support. Then, I never turn to them, instead but instead to temporary work agency or I am trying to get support from home [...]. When I have stayed longer at a client organization, well then you kind of becomes more like an regular nurse. Then you get to know the manager and some of the regular nurses more and can be supported by them.

This theme illustrated how relations with regular nurses and client organization managers were decisive for feedback and support in daily work. As these emerged as functional but highly varied, it also illustrated conditions for feedback and support in daily work as highly varied.

Temporary work agency as employer at distance with varying offers.

It was evident from the analysis that contact with temporary work agency varied significantly in terms of both frequency and focus. While contact was described to take place almost solely by telephone or email (due to geographical distance), how often one had contact with the temporary work agency varied from sporadic to fairly regularly. Likewise, what were discussed with temporary work agency varied from clearly focused on practical issues, to more focused on work at client organizations. For example, one temporary agency nurse described how the temporary work agency helped her with bus tickets and provided feedback: 'Yes, I like that you are so independent and take care of your papers and such' (I1). Another interviewee described how contact with the temporary work agency revolved around contracts, salary and such things. She said: 'So, yes, it is just such things. It's nothing else' (I3). Some temporary agency nurses also mentioned the difficulty with temporary work agencies providing feedback as they lacked 'insight into health care and nursing' (I6) and highlighted new assignments (absence of complaint) as constituting feedback:

If you do not hear anything, it is good! That's what the temporary work agency says, because I have asked, and then ... And, well, I have been hired by the same client organization repeatedly, and then you just have to feel like, 'Yes, then they probably felt it worked!' So, well, that's it; there is no other feedback than that. (I9) 
By contrast, other temporary agency nurses described the contact as more focused on work, how temporary work agencies had acted in connection with problems at client organizations, by contacting client organization managers to discuss perceived problems. Indeed, one interviewee, whose temporary work agency manager was a nurse, described how she 'for the first time receiving substantial feedback' (I4).

Clear differences in what temporary work agencies offer were also illustrated; while some temporary agency nurses described how the temporary work agency provided access to relevant journals, educational databases and sometimes arranged courses (for example in cardiopulmonary resuscitation), others either said that they had heard about such opportunities but had never received such offers or had not taken the initiative to participate, or, that they had explicitly asked for courses but that the temporary work agency did not offer them. One temporary agency nurse said she had asked for courses, but that the temporary work agency had not been able to respond to that. 'They have simply said that they do not have the courses. That they may arrange it in the future, or that if you can get a course at the client organization, we will pay for it' (I5). Some temporary agency nurses, who had been offered shorter courses or lectures by their temporary work agencies, also described obstacles to participation in terms of distance and few options:

There may be an email that 'Now it's a lecture', and it is always in a city far away from here. Like, a single date and time. So, it's a bit difficult for us who live here to take part. (I5)

This theme illustrated how the overall meaning of the relationship with temporary work agency varied and thus, implied highly varied conditions for support, feedback and learning due to distance between temporary work agency and agency nurse, to whether the temporary work agency had nursing competence or not, and whether the temporary work agency are offering courses or not.

\section{Diverging Views on and Evaluations of Prevailing Working and Learning Conditions}

This theme illuminated how expressions of what we interpreted as illustrating diverging views on and evaluations of prevailing working and learning conditions were related to: 'The significance of view on nursing, starting point and future plans' and 'Different views on responsibility for learning', also constituting the two sub-themes here.

The significance of view on nursing, starting point and future plans.

As evident from the analysis, the temporary agency nurses' view on nursing, starting point (in terms of competence and current work situation) and future plans emerged as important for how prevailing working and learning conditions were evaluated.

Firstly, while some interviewees discussed a limited contribution and participation at client organizations as unproblematic, or even as an advantage of being temporary agency nurse as this implied more opportunities for 'real nursing' (opportunity to focus on patient-related tasks) instead of administrative work and social 'fuss', oth- 
ers explicitly problematised this. For example, one temporary agency nurse said she struggled somewhat with accepting 'not to care about tomorrow as much as I would as a regular nurse' (I4). Indeed, some explicitly mentioned how they sometimes missed continuity in relation to patients and staff. We regard this as an illustration of how different views on nursing implies partly different evaluations of current working- and learning conditions.

Secondly, while some interviewees problematized constrained conditions for feedback and support relating to both client organizations and temporary work agencies, others emphasized how other assignments (through employers) provided necessary feedback and support. For example, one interviewee said she received necessary feedback via other assignments, but said that otherwise it 'might have been in a different way' (I3). By contrast, others problematized temporary work agencies not being represented in daily work. For example, regarding this, one temporary agency nurse said: "Sometimes I have thought about it in relation to, well, little things that can happen. Like 'Where is my support' and 'How do I get my support' (I5). Some temporary agency nurses also stressed how their competence compensated for sometimes lacking support, feedback etc. One interviewee even said she once declined an offer of induction training because of her nursing competence (I13). This illustrates how the interviewees' starting point, in terms of their competence and whether they worked solely as temporary agency nurses or not, were employed by one or several temporary work agencies etc., mattered when evaluating their current working and learning conditions.

Thirdly, while the majority of the temporary agency nurses explicitly mentioned few opportunities for courses and lectures as a negative aspect of temporary agency work, others said that learning mattered less as they planned to work as an 'temp' for a limited period, and they would focus on competence development later, or as that they were ending their careers as nurses soon. Some also mentioned that other employers fulfilled this need or emphasised that their current conditions did not differ much from working as an regular nurse for public employers.

This theme illustrated the significance of the interviewees' individual view on nursing, one's own competence and current work situation (starting point) and future plans when they evaluated their working and learning conditions.

Different views on responsibility for learning.

Based on the analysis, three different views on responsibility for learning emerged among the interviewees. Some temporary agency nurses clearly connected temporary agency work to increased individual responsibility for learning because neither temporary work agency nor client organizations offered such activities. For example, one interviewee said:

It is the Achilles' heel for us as workers; we are not part of a group or a collective. [...] Thus, as an temporary agency nurse, I must probably see it as my own responsibility, but society should take greater responsibility and perhaps place that responsibility on the temporary work agency as employer. (I8) 
Related to such experiences, some mentioned that they did not know how to find courses, that is who organized courses possible for temporary agency nurses to take part in.

By contrast, others placed the responsibility primarily with the temporary work agency or the client organization. Within the latter group, some noted that it might not be in 'the interest of the client organization' (I6), whereas others expressed clear expectations of being allowed to participate in activities arranged at the client organization. One interviewee said the following regarding her not being able to participate in a course arranged at a client organization:

I thought I could get in for free, if only I could join! Because I had like, none ... But 'No, you cannot - it's only for employees'. And, of course, I might be able to take a course at the Red Cross instead; I can, but I think it's a bit weird that there is none, I mean, we are not that many ... But, yes, I understand that we are treated a little harsh; we cannot take it for granted, because it certainly stands out that we have a higher salary than them and such. (I9)

Thus, this theme illustrates how the understanding and view of responsibility for learning varied between the interviewees.

\section{Discussion}

Obviously, the findings illustrate workplace learning as both enabled and constrained. First, how moving between various client organizations promote informal learning by providing opportunities for job rotation, variation (Ellström, 1992; Eraut; 2004) and versatility, the latter of which is linked to nurses' individual development (Järvi \& Uusitalo, 2004). Moreover, the findings illustrate the importance of competence (ability to handle challenges) as well as self-confidence among the interviewees. As these aspects are highlighted as crucial for workplace learning (Eraut, 2004, 2011), and as motivation and the assessment of one's own capacity are stressed as important for forming an interest in learning (Kyndt \& Baert, 2013), this reflects informal learning as enabled. This can also be discussed as reflecting how nursing (in itself) is characterised of favourable conditions for workplace learning through variation, autonomy, complex tasks, opportunities for collaboration etc. (Ellström, 2001; Eraut, 2004). Indeed, the findings illuminate overall well-functioning intra-professional relations (e.g. with regular nurses), and daily work as 'regular nursing'.

At the same time, support and feedback emerge as varied and general rather than work related and specific (cf. Berg Jansson et al., 2020) due to, in relation to temporary work agencies, distance and/or lack of nursing competence. Likewise, in client organizations, support and feedback appear as random rather than planned, and to vary according to relations with regular staff. The anecdotes about new assignments functioning as feedback illustrate this. Hence, these aspects emerge as dependent on the quality of relationships with the client organization as well as on the competence and offers of the temporary work agency, and thus, not only as weak but also highly varied. Indeed, the stressing of competence and experience as crucial in daily work, 
can be discussed as reflecting this. Because workplace learning is discussed as a social activity requiring 'reflection on past experiences and the planning of future activities' (Tynjälä, 2008, p. 135), in which feedback and support are crucial (Ellström, 2001; Eraut, 2004), this mirrors challenges for informal learning. In fact, feedback is discussed as essential to job-specific and generic informal learning among nurses (Kyndt et al., 2016). The findings also illustrate scarce opportunities and low expectations for the temporary agency nurses' participation in development work (cf. Allvin et al., 2003; Augustsson, 2016; Berg Jansson et al., 2020; Cornes et al., 2013) indicate how cultural elements of daily work 'teach' temporary agency nurses not to question routines, etc. Thus, limited opportunities for the temporary agency nurses to join in developing work processes and a holistic understanding of organisational matters. Although not all the interviewees identified this as problematic, this is relevant, as these aspects are vital to workplace learning (Ellström, 2001). Moreover, the findings show few and varying opportunities for formal learning related to both temporary work agencies and client organizations. The findings also show some indirect challenges to participation in formal learning, in terms of 'when and where' such activities are arranged by temporary work agencies, reflecting Manthorpe et al.'s (2012) description of how practical difficulties in taking shorter courses, etc., hamper the training and professional development of temporary agency workers in social care (cf. Kost et al., 2020). Altogether, this shows that, although the findings of this study indicate some opportunities for informal learning, challenges persist not only regarding conditions for formal learning but also in terms of partly challenged conditions for informal learning. In all, besides that the findings illustrate an overall tension between enabling and constraining features characterizing temporary agency nurses work situation, it is also possible to discern some other tensions between the identified subthemes. Namely, between 'daily work as regular nursing but limited participation at client organizations', 'nursing as common ground but decisive relations as clearly varied' and 'nursing as valued and recognized competence but as partly underused and not focused'. We regard these not only as an illustration of differences regarding the interviewees' evaluations of prevailing working and learning conditions but also how the interviewees' touched on some clear differences between working as an temporary agency nurse and regular nurse, respectively, although some explicitly said that there were no such differences in daily work.

What, then, is the significance of the above? This qualitative study enables discussion of the prevailing conditions at the individual level and suggests that the significance of eventual challenges partly depends on individual factors, such as competence, future plans, etc. Despite this, the findings highlight more overarching questions regarding workplace learning in this context, important to address in future research. Firstly, the fact that temporary agency nurses do not take part in organisational processes and 'learn' to focus on practical work and not question routines etc., indicates few opportunities to question and influence prevailing conditions (tasks and goals), characterising developmental learning (Ellström, 2001), and can be interpreted as reflecting incidental learning (Marsick \& Watkins, 2001). This is in line with Augustsson's (2016) discussion of how client organizations marginally use the capacity of highly skilled temporary agency workers, and with Manuti et al.'s (2015) discussion of learning awareness as mediated by occupational condition. Further- 
more, Ekberg (2014) discusses how, although today's working life clearly demands developmental learning to increase individual participation and contributions, the conditions of temporary agency workers offer few opportunities to participate in developmental learning due to detailed descriptions, working methods, etc. Although this 'risk' is not directly transferable to the temporary agency nurses, since they are highly qualified and nursing is characterised by variation, discretion etc. "strengthening' workplace learning (Ellström, 1992, 1996, 2001), a tendency towards adapting to prevailing conditions, goals etc. rather than engaging in developmental learning can be discerned in the findings of this study. This also indicates that temporary agency nurses risk being left without opportunities to work on quality improvement, described as a core competence for nurses (SweNurse, 2017).

Secondly, besides that formal learning is stressed as crucial to effectively exploiting informal learning (Tynjälä \& Virtanen, 2005), the lack of formal learning also represents a potential challenge to individual temporary agency nurses; as informal learning does not provide qualifications and formal merits, it does not enhance employability as does formal learning (cf. Augustsson, 2016). As succinctly described by Hilkenmeier et al., (2021), workplace learning (comparable to what we in this paper discuss as informal learning), that is learning activities driven by employees' needs to tackle unfolding or pressing work tasks “... do not aim at knowledge and skill development that could help employees in a more or less distant future. Instead, these activities aim at coming up with suitable strategies to tackle the situation currently at hand" (p. 413). Furthermore, although knowledge and skill acquisition is highly relevant side-effects of such activities, such 'positive effects' most likely remains highly contextualized and thus limited (Hilkenmeier et al., 2021). This also reflects how work tasks and environments are still controlled by client organizations, making it hard for individual temporary agency workers to take responsibility for skills, social integration, etc. as assumed by advocates of the boundaryless career perspective (Kost et al., 2020). Of course, conditions also vary in more traditional (stable) forms of employment, where learning conditions for regular nurses are not necessarily better (cf. Forrier \& Sels, 2003; Bonet et al., 2013). In fact, Adams and Sawchuk (2020) describe how nurses, amidst changing organisational life and work processes, '...have less time to think critically, to exercise judgement, to acquire knowledge they associate specifically with their profession, and to exercise suitable levels of autonomy and influence over what they learn, how and why' (p. 15). Nevertheless, as '... necessary work always will receive higher priority than learning-oriented measures' (Illeris, 2011, p. 40), the temporary agency nurses' descriptions of daily work as mainly taking care of the most urgent matters suggest that this challenge is even greater for temporary agency nurses.

This raises the broad question of if and how the integration between work and learning can be strengthened for temporary agency nurses. As Illeris (2011) notes, in the modern-market society short-term needs are focused in pressing situations, and thus also, learning 'by chance' at work which neither costs nor demands priority but comes 'by itself' and improves the here and now. Thus, how up-to-date competence development (in general) is a challenge that demands increased cooperation between education and training institutions as well as private and public workplaces, including increased costs for all parties (Illeris, 2011). This study suggests that although some 
learning opportunities were illustrated, this challenge may be even greater for temporary agency nurses, as conditions for workplace learning were highly dependent not only on the offers of specific temporary work agencies and client organizations, but also on temporary agency nurses' interest in and views regarding responsibility for learning, and thus highly varying. The findings thus underline the need for more research focusing on understanding conditions for integrating work and learning in temporary agency work in a professional context. In this vein, the findings also suggest the need to develop the theoretical understanding of conditions for workplace learning in situations characterised by work in several organisational contexts and where the learning environment is related to several actors rather than to an employing organisation. This is crucial in light of temporary agency nurses' belonging to a welfare sector professional group that is important to the development and innovation of health care and because temporary hiring is increasingly common among other welfare sector professional groups in health care (National Board of Health and Welfare 2018).

Funding Open access funding provided by Lulea University of Technology. The research in this article was funded by The Swedish Research Council for Health, Working Life and Welfare (FORTE), dnr: 2016-01003.

Open Access This article is licensed under a Creative Commons Attribution 4.0 International License, which permits use, sharing, adaptation, distribution and reproduction in any medium or format, as long as you give appropriate credit to the original author(s) and the source, provide a link to the Creative Commons licence, and indicate if changes were made. The images or other third party material in this article are included in the article's Creative Commons licence, unless indicated otherwise in a credit line to the material. If material is not included in the article's Creative Commons licence and your intended use is not permitted by statutory regulation or exceeds the permitted use, you will need to obtain permission directly from the copyright holder. To view a copy of this licence, visit http://creativecommons.org/ licenses/by/4.0/.

\section{References}

Adams, T., \& Sawchuk, P. H. (2020). Professional-organizational contradictions and hybridization of knowledge: Insights from the study of engineering and nursing in Canada. Vocations and Learning. https://doi.org/10.1007/s12186-020-09253-1

Ahlstedt, C., Eriksson Lindvall, C., Holmström, I. K., \& Muntlin Athlin, Å. (2019). What makes registered nurses remain in work? An ethnographic study. International Journal of Nursing Studies, 89, 32-38. https://doi.org/10.1016/j.ijnurstu.2018.09.008

Allvin, M., Aronsson, G., Hagström, T., Johansson, G., \& Lundberg, U. (2006). Gränslöst arbete: Socialpsykologiska perspektiv på det nya arbetslivet. Malmö: Liber

Allvin, M., Jacobson, A., \& Isaksson, K. (2003). Att avgränsa det gränslösa sjuksköterskearbetet: En intervjustudie om sjuksköterskors villkor och valmöjligheter $i$ bemanningsbranschen. Stockholm: Arbetslivsinstitutet

Augustsson, G. (2014). Temporary and regular workers fulfill their tasks side-by-side, but in different learning conditions. Journal of Workplace Learning, 26(2), 79-90

Augustsson, G. (2016). The client company marginally utilizes the knowledge of highly skilled temporary staff. Journal of Education and Work, 29(5), 519-539

Bellaagh, K., \& Isaksson, K. (1999). Uthyrd men fast anställd (Arbete \& Hälsa, 1999:6). Stockholm: Arbetslivsinstitutet 
Berg Jansson, A., Engström, Å., \& Parding, K. (2020). What about learning? A study of temporary agency staffing and learning conditions in Swedish healthcare. Journal of Workplace Learning, 32(1), 63-75. https://doi.org/10.1108/JWL-06-2018-0083.

Billett, S. (2001). Learning through work: workplace affordances and individual engagement. Journal of Workplace Learning, 13(5), 209-214

Billett, S. (2004). Learning through work: workplace participatory practices. In H. Rainbird, A. Fuller, \& A. Munro (Eds.), Workplace Learning in Context (pp. 109-125). Routledge

Billett, S. (2010). The Relational Interdependence between Personal and Social Agency in Learning and for Working Life. In M. Van Woerkom, \& R. Poell (Eds.), Workplace Learning. Concepts, Measurment, and Application (pp. 11-25). Routledge

Billett, S., Harteis, C., \& Gruber, H. (2014). Introduction. In S. Billett, C. Harteis, \& H. Gruber (Eds.), International Handbook in Professional and Practice-Based Learning (pp. 17-21). Springer

Bonet, R., Capelli, P., \& Harmori, M. (2013). Labor market intermediaries and the new paradigm for human resources. Academy of Management Annals, 7(1), 341-392. https://doi.org/10.1080/194165 20.2013.774213

Bosmans, K., De Cuyper, N., Hardonk, S., \& Vanroelen, C. (2015). Temporary agency workers as outsiders: An application of the established-outsider theory on social relations between temporary agency and permanent workers. Society, Health and Vulnerability, 6(1), 27848. https://doi.org/10.3402/vgi. v6.27848

Braun, V., \& Clarke, V. (2006). Using thematic analysis in psychology. Qualitative Research in Psychology, 3(2), 77-101

Charnley, D., \& Arnold, J. (2006). Work relationships between agency and permanent staff. Nursing Times, 102(35), 34-38

Cicellin, M., Pezzillo Iacono, M., Berni, A., \& Esposito, V. (2015). Dealing with resistance in temporary agency nurses. The role of fear in identity-building processes. Journal of Health Organization and Management, 29(3), 298-316

Cornes, M., Manthorpe, J., Moriarty, J., Blendi-Mahota, S., \& Hussein, S. (2013). Assessing the effectiveness of policy interventions to reduce the use of agency or temporary social workers in England. Health and Social Care in the Community, 21(3), 236-244

Ekberg, K. (2014). Hälsofrämjande och lärande arbetsplats - finns organisatoriska förutsättningar? In H. Kock (Ed.), Lärande i arbetslivet. Möjligheter och utmaningar. En vänbok till Per-Erik Ellström. u.o

Ellström, P. E. (1992). Kompetens, utbildning och lärande i arbetslivet. Problem, begrepp och teoretiska perspektiv. Stockholm: Publica

Ellström, P. E. (1996). Arbete och lärande-förutsättningar och hinder för lärande i dagligt arbete. Solna: Arbetslivsinstitutet

Ellström, P. E. (2001). Integrating learning and work: Problems and prospects. Human Resource Development Quarterly, 12(4), 421-435

Ellström, P. E. (2004). Reproduktivt och utvecklingsinriktat lärande i arbetslivet. In P. E. Ellström, \& G. Hultman (Eds.), Lärande och förändring i organisationer. Lund: Studentlitteratur

Ellström, P. E. (2011). Informal learning at Work: Conditions, Processes and Logics. In M. Malloch, L. Cairns, K. Evans, \& B. N. O’Connor (Eds.), The SAGE Handbook of Workplace Learning. Sage

Ellström, E., Ekholm, B., \& Ellström, P. E. (2007). Two types of learning environment. Enabling and constraining. A study of care work. Journal of Workplace Learning, 20(2), 84-97

Eraut, M. (2004). Informal learning in the workplace. Studies in Continuing Education, 26(2), 247-273

Eraut, M. (2011). How researching learning at work can lead to tools for enhancing learning. In M. Malloch, L. Cairns, K. Evans, \& B. N. O’Connor (Eds.), The SAGE Handbook of Workplace Learning. Sage

Forrier, A., \& Sels, L. (2003). Temporary employment and employability: Training opportunities and efforts of temporary and permanent employees in Belgium. Work, Employment and Society, 17(4), 641-666

Freidson, E. (2001). Professionalism: The Third Logic. Polity Press

Fuller, A., \& Unwin, L. (2004). Expansive Learning Environments: Integrating Organisational and Personal Development. In H. Rainbird, A. Fuller, \& A. Munro (Eds.), Workplace Learning in Context (pp. 126-144). Routledge

Garsten, C. (1999). Betwixt and between: Temporary employees as liminal subjects in flexible organizations. Organizations Studies, 20(4), 601-617

Garsten, C. (2008). Workplace vagabonds: Career and community in changing worlds of work. Palgrave Macmillan 
Hager, P. (2011). Theories of workplace learning. In M. Malloch, L. Cairns, K. Evans, \& B. N. O’Connor (Eds.), The SAGE Handbook of Workplace Learning. Sage

Hilkenmeier, F., Goller, M., \& Schaper, N. (2021). The Differential Influence of Learner Factors and Learning Context on Different Professional Learning Activities. Vocations and Learning, 14, 1-28. https://doi.org/10.1007/s12186-021-09266-4

Håkansson, K., \& Isidorsson, T. (2015). Temporary Agency Workers-Precarious Workers? Perceived Job Security and Employability for Temporary Agency Workers and Client Organization Employees at a Swedish Manufacturing Plant. Nordic Journal of Working Life Studies, 5(4), 3-22. https://doi. org/10.19154/njwls.v5i4.4841

Håkansson, K., \& Isidorsson, T. (2016). Användningen av inhyrd arbetskraft i Sverige. Arbetsmarknad \& Arbetsliv, 22(3/4), 47-67

Hass, H., Coyer, F., \& Theobald, K. (2006). The experience of agency nurses working in a London teaching hospital. Intensive and Critical Care Nursing, 22(3), 144-153

Illeris, K. (2011). The fundamentals of workplace learning: Understanding how people learn in working life. Routledge

Järvi, M., \& Uusitalo, T. (2004). Job rotation in nursing: A study of job rotation among nursing personnel from the literature and via a questionnaire. Journal of Nursing Management, 12(5), 337-347

Kirkpatrick, I., Hoque, K., \& Lonsdale, C. (2018). Client organizations and the management of professional agency work: The case of the English health and social care. Human Resource Management, 1-14. https://doi.org/10.1002/hrm.21933

Knutsen, H. M. (2019). Health Institutions, Temporary Work Agencies, and the Mobility Power of Nurses. Nordic Journal of Working Life Studies, 8(4), https://doi.org/10.18291/njwls.v8i4.111927

Kost, D., Fieseler, C., \& Wong, S. I. (2020). Boundaryless careers in the gig economy: An oxymoron? Human Resource Management Journal, 30(1), 100-113

Kyndt, E., \& Baert, H. (2013). Antecedents of employees' involvement in work related learning: A systematic review. Review of Educational Research, 83(2), 273-313

Kyndt, E., Vermeire, E., \& Cabus, S. (2016). Informal workplace learning among nurses. Journal of Workplace Learning, 28(7), 435-450. https://doi.org/10.1108/JWL-06-2015-0052

Lincoln, Y., \& Guba, E. G. (1985). Naturalistic inquiry. Sage

Manias, E., Aitken, R., Peerson, A., Parker, J., \& Wong, K. (2003). Agency-nursing work: Perceptions and experiences of agency nurses. International Journal of Nursing Studies, 40(3), 269-279

Manthorpe, J., Cornes, M., \& Moriarty, J. (2012). Considering the safeguarding risks presented by agency or temporary social care staff: Research findings and recommendations. Journal of Adult Protection, 14(3), 122-130

Manuti, A., Pastore, S., Scardigno, A. F., Giancaspro, M. L., \& Morciano, D. (2015). Formal and informal learning in the workplace: A research review. International Journal of Training and Development, 19(1), 1-17

Marsick, V. J., \& Watkins, K. (1990). Informal and incidental learning in the workplace. Routledge

Marsick, V. J., \& Watkins, K. E. (2001). Informal and incidental learning. New Directions for Adult and Continuing Education, 89, 25-34

National Board of Health and Welfare (2018). Bedömning av tillgång och efterfrågan på personal $i$ hälsooch sjukvård och tandvård. Nationella planeringsstödet 2018. Retrieved May 6, 2019, from: https:// www.socialstyrelsen.se/Lists/Artikelkatalog/Attachments/20880/2018-2-23.pdf

Nowell, L. S., Norris, J. M., White, D. E., \& Noules, N. J. (2017). Thematic analysis: striving to meet the trustworthiness criteria. International Journal of Qualitative Methods, 16(1), 1-13

OECD (2017). Sweden: Country Health Profile 2017, State of Health in the EU, OECD Publishing, Paris/European Observatory on Health Systems and Policies, Brussels. https://oi. org/10.1787/9789264283572-en

Patton, M. Q. (2015). Qualitative research and evaluation methods: Integrating theory and practice (4th ed.). Sage

Puhakka, I., Nokelainen, P., \& Pylväs, L. (2021). Learning or Leaving? Individual and Environmental Factors Related to Job Satisfaction and Turnover Intention. Vocations and Learning, 14, 481-510. https://doi.org/10.1007/s12186-021-09275-3

Ronnie, R. (2020). Us and them: Experiences of agency nurses in intensive care units. Intensive \& Critical Care Nursing, 56, https://doi.org/10.1016/j.iccn.2019.102764

Sennett, R. (2000). När karaktären krackelerar. Människan i den nya ekonomin. Stockholm: Atlas

SALAR (2021). Local self-government, received 12th October from https://skr.se/skr/tjanster/englishpages/municipalitiesandregions/localselfgovernment.1305.html 
SALARa (n.d.). Kostnader för inhyrd personal i hälso-och sjukvården. Retrieved March 1, from: https:// skr.se/download/18.4402e18716b630bd97a1719a/1560782832519/Bemanningstrend\%20i\%20 hälso-\%20och\%20sjukvården\%20kvartal\%204\%202018.pdf

SALARb (n.d.). Kostnader för inhyrd personal i hälso-och sjukvården. Retrieved March 1, from: https://skr.se/download/18.30233521174b9d2f82ae196e/1601551849958/Kostnader_for_inhyrd personal_i_halso_och_sjukvarden_halvar1_2020.pdf

Slotte, V., Tynjälä, P., \& Hytönen, T. (2004). How do HRD practitioners describe learning at work? Human Resource Development International, 7(4), 481-499

SweNurse (2017). Competence description for a registered nurse. Retrieved from: http://www.swenurs. se/globalassets/01-svensksjuksköterskeförening/publikationer-svensk-sjukskoterskeforening/kompetensbeskrivningarpublikationer/kompetensbeskrivning-legitimerad-sjukskoterska-2017-for-webb. pdf

Svensson, L. G. (2008). Profesjon og organisasjon. In A. Molander, \& L. I. Terum (Eds.), Profesjonsstudier. Oslo: Universitetsforlaget

Swedish Research Council. (2017). Good research practice. Swedish Research Council

Tynjälä, P. (2008). Perspectives into learning at the workplace. Educational Research Review, 3(2), $130-154$

Tynjälä, P., \& Virtanen, A. (2005). Skill learning at work: Investigation into student experiences of on-thejob learning. Learning the skills: Special edition of the Finnish Journal of Vocational and Professional Education, 7(special edition), 106-116

Tynjälä, P. (2013). Toward a 3-P model of workplace learning: a literature review. Vocations and Learning, 6, 11-36. https://doi.org/10.1007/s12186-012-9091-z

Publisher's Note Springer Nature remains neutral with regard to jurisdictional claims in published maps and institutional affiliations.

Anna Berg Jansson is Senior Lecturer in Sociology at the Division of Human Work Science, Luleå University of Technology, Sweden. Her main research interest lies in nurses' working- and learning conditions related to different kinds of organizational changes. Currently, her research focuses on how temporary agency staffing within Swedish healthcare can be understood in relation to conditions for learning from an individual and organizational perspective.

Åsa Engström is Professor of Nursing in the Division of Nursing and Medical Technology, Department of Health Learning and Technology, Lulea University of Technology, Sweden. Her research interest is foremost within nursing research in emergency/intensive care with the perspective from registered nurses, patients and their relatives. Another research interest is about learning in working life.

\section{Authors and Affiliations}

\section{Anna Berg Jansson ${ }^{1}$ Åsa Engström ${ }^{2}$}


Anna Berg Jansson

anna.jansson@1tu.se

Åsa Engström

asa.engstrom@1tu.se

1 Department of Social Sciences, Technology and Arts, Luleå University of Technology,

Porsö Campus, A138, 97187 Luleå, Sweden

2 Department of Health, Education and Technology, Luleå University of Technology, Porsö Campus, S301, 97187 Luleå, Sweden 